\title{
Implementasi Manajemen Strategik Dalam Lembaga Pendidikan
}

\author{
Muhammad Fadhli ${ }^{1}$ \\ 1IAIN Lhokseumawe, Indonesia
}

Corresponding Author: Muhammad Fadhli, @fadhlikhan88@gmail.com

\section{ARTICLE INFO \\ Article history: \\ Received}

Revised

Accepted

\begin{tabular}{l} 
ABSTRACT \\
\hline Manajemen strategis merupakan implementasi perencanaan, \\
pemantauan, analisis, dan evaluasi yang dilakukan secara berkelanjutan \\
dari semua kebutuhan yang diperlukan oleh organisasi dalam upaya \\
mencapai tujuannya. Perubahan yang terjadi secara cepat dan spontan di \\
lingkungan organisasi akan membutuhkan organisasi yang mampu untuk \\
terus melakukan evaluasi strategi. Implementasi manajemen strategis \\
membantu organisasi mengetahui kondisi organisasi saat ini, kemudian \\
menyusun strategi, menyebarkannya dan menganalisis keefektifan \\
strategi manajemen yang diterapkan. Penelitian ini bertujuan untuk \\
mengetahui implementasi manajemen strategi dalam lembaga \\
pendidikan. Penelitian ini menggunakan studi kepustakaan (library \\
research). Dalam memperoleh data penelitian, peneliti mengumpulkan, \\
menganalisis, mengorganisasi, sumber dari artikel, buku, penelitian \\
terdahulu tentang implementasi manajemen strategi dalam bidang \\
pendidikan. Hasil penelitian menemukan bahwa dalam implementasi \\
manajemen strategik lembaga pendidikan harus merumuskan beberapa \\
aspek, yaitu: 1) visi, misi dan nilai-nilai lembaga pendidikan, 2) tujuan \\
jangka panjang, 3) menentukan strategi priorotas, 4) menyusun indikator \\
kinerja, 5) menguraikan tujuan secara operasional, 6) memperhatikan \\
kebutuhan sumber daya (fisik, manusia, keuangan), 7) memantau dan \\
melaksanakan perencanaan operasional secara rutin dan terjadwal.
\end{tabular}

Manajemen, Strategik, Lembaga Pendidikan

Name. (2020). Tittle. Journal Continuous Education, 1(1). 11-23

http://pusdikra-publishing.com/index.php/josr/index

How to cite

\section{PENDAHULUAN}

Pencapaian tujuan organisasi yang efektif dan efisien merupakan impian seluruh anggota organisasi. Sama halnya dengan organisasi pada umumnya, dalam organisasi pendidikan pencapain kinerja orgnisasi yang unggul dan efektif juga menjadi fokus bagi para pengelola pendidikan.

Perkembangan dan perubahan dunia yang semakin cepat merupakan tantangan bagi lembaga pendidikan. Perkembangan yang cepat ini terjadi secara terus menerus. Dampak globalisasi, perkembangan ilmu pengetahuan dan teknologi, model dan metode pembelajaran terbaru, perubahan demografi, dan ketidakpastian ekonomi dunia serta tuntutan masayarakat yang semakin beragam merupakan tantangan yang harus dijawab dan diantisipasi oleh pengelola lembaga pendidikan. 
Lembaga pendidikan yang berkualitas merupakan harapan bagi masyarakat. Namun pada kenyataannya lembaga pendidikan indonesia belum mampu menunjukkan peningkatan mutu secara merata dan berkelanjutan. Hal ini ditandai dengan belum mampunya lembaga pendidikan kita menghasilkan pemerataan sumberdaya manusia yang mampu bersaing di dunia intenasional.

Berdasarkan data yang dikeluarkan oleh The Learning Curve Pearson pada tahun 2014, sebuah lembaga pemeringkatan pendidikan dunia, di jelaskan bahwa jika Indonesia menduduki tempat akhir dalam hal mutu pendidikan di seluruh dunia. Indonesia hanya mampu menempati posisi ke-40 dengan indeks rangking dan nilai secara keseluruhan yakni minus (-) 1,84 . Sementara pada kategori kemampuan kognitif indeks rangking 2014 Indonesia diberi nilai -1,71(Lestarini, 2014). Hal ini tentunya menjadi pukulan bagi pengelola pendidikan mulai dari pemerintah pusat, pemerintah daerah dan juga stakeholder lainnya.

Indikator lainnya yang dapat dilihat secara nyata bahwa mutu pendidikan di Indonesia belum mampu memenuhi harapan yaitu: 1). kualitas sarana fisik yang belum merata, 2). Kompetensi dan kualitas guru, 3). kesejahteraan guru terutama guru honorer (non PNS), 4). prestasi siswa yang belum maksimal, 5). Kurangnya pemerataan kesempatan pendidikan, 6). relevansi kurikulum pendidikan dengan kebutuhan masyarakat, dan 7). Mahalnya biaya pendidikan.

Rendahnya mutu pendidikan saat ini merupakan dampak dari ketidakmampuan lembaga pendidikan menyesuaikan dengan perkembangan dan perubahan zaman. Keerlambatan penyesuaian diri akan menyebabkan lembaga pendidikan tersebut tergerus dan akan ditinggalkan oleh pelanggan jasa pendidikan itu sendiri.

Selama beberapa dekade terakhir sistem pendidikan telah mengalami proses restrukturisasi yang panjang dari model manajemen pendidikan yang berakar kuat di masa lalu menjadi model manajemen strategik yang difokuskan pada masa depan (Latorre-Medina \& Blanco-Encomienda, 2013). Oleh karena itu, implementasi manajemen strategik dalam pendidikan dirasa penting diimplementasikan bagi keunggulan organisasi pendidikan. Lemahnya kemampuan pendidikan dalam upaya pencapain keunggulan organisasi perlu untuk dilakukan usaha-usaha nyata. Usaha nyata itu dimulai dari implementasi manajemen strategik.

Stukalina dalam studinya memenuhkan manajemen pendidikan yang strategik memilki keterkaitan dengan penciptaan lingkungan pendidikan yang konstruktif yang bertujuan untuk mendukung proses pembelajaran yang berkelanjutan (Stukalina, 2010). Manajemen strategik dapat dikatakan sebagai penggerak program inovatif dalam pendidikan dengan penekanan pada sumber daya manusia. Baltabayeva dalam penelitiannya membuktikan bahwa manajemen strategik dapat mengurangi risiko pada organisasi pendidikan dan kemudian mengubahnya menjadi bidang peluang baru (Baltabayeva et al., 2020). Implementasi manajemen strategik pada lembaga pendidikan dapat memberikan dampak positif pada pengembangan lembaga pendidikan. 
Manajemen strategik memberikan petunjuk tentang mengatasi masalahmasalah dan memberikan peluang pada saat sekarang dan di masa yang akan datang. Selain itu akurasi dalam pembuatan keputusan serta implementasinya dapat dilakukan dengan lebih baik (Mappasiara, 2018).

Bidang manajemen strategik menyajikan banyak jalan yang kaya dan bermanfaat untuk melakukan penelitian. Hal yang sama juga berlaku untuk dalam proses pendidikan. Strategi memiliki fakta untuk menggabungkan banyak perspektif teoretis dan mencakup banyak topik yang beragam memungkinkan adanya variasi yang luar biasa dalam implementasinya di lembaga pendidikan (Kesner, 2017). Implementasi manajemen strategik pada lembaga profit sudah menunjukkan keberhasilan perusahaan-perusahaan mencapai keunggulan yang kompetitif. Untuk itu tulisan ini akan membahas imlementasi manajemen strategik pada lembaga pendidikan.

\section{METODE PENELITIAN}

Penelitian ini menggunakan studi kepustakaan (library research). Dalam memperoleh data penelitian, peneliti mengumpulkan, menganalisis, mengorganisasi, sumber dari artikel, buku, penelitian terdahulu tentang implementasi manajemen strategi dalam bidang pendidikan. Kemudian peneliti menyimpulkan dan menyajikan data-data manajemen strategi untuk peningkatan mutu pendidikan (Danandjaja, 2014; Sari \& Asmendri, 2020; Zed, 2014).

\section{HASIL DAN PEMBAHASAN}

\section{Konsep Strategi dan Manajemen Strategik}

Manajemen strategik muncul dan dipraktikkan awalnya pada dunial militer. Pada awal tahun 1970-an, para pengajar dan peneliti kebijakan bisnis mulai melakukan pertemuan untuk mendiskusikan mengenai perubahanperubahan yang terjadi pada praktek-praktek kebijakan bisnis dan bagaimana mereka meresponnya. Pada tahun 1977 diselenggarakan sebuah konferensi di universitas pittsburgh yang melahirkan apa yang kemudian dikenal sebagai strategic management (Sampurno, 2013).

Sebelum membahas lebih lanjut tentang defenisi menajemen strategik, maka lebih tepat untuk memahmi tentang strategi. Banyak defenisi yang dapaat menggambarkan strategi diantaranya Hitt, Ireland dan Hoskisson menjelaskan "A strategy is an integrated and coordinated set of commitments and actions designed to exploit core competencies and gain a competitive advantag(Hitt et al., 2011)". Pendapat ini menjelaskan bahwa strategi merupakan serangkaian komitmen dan tindakan terpadu serta terkoordinasi yang dirancang untuk memaksimalkan kompetensi inti dan mendapatkan keunggulan kompetitif pada organisasi. Pada saat memilih strategi, organisasi membuat dan mengembangan pilihan di antara alternatif yang ada untuk memutuskan bagaimana organisasi akan mengejar daya saing strategik. Strategi yang dipilih akan menunjukkan apa yang akan dilakukan dan tidak akan dilakukan organisasi. 
Kemudian Rothaemel (2017)memberikan penambahan bahwa "strategy is a set of goal-directed actions a firm takes to gain and sustain superior performance relative to competitors". Defenisi ini menjelaskan bahwa strategi adalah serangkaian tindakan yang diarahkan pada tujuan yang diambil oleh organisasi untuk mendapatkan dan mempertahankan kinerja yang unggul dibandingkan dengan pesaing. Defenisi lebih memfokuskan pada tujuan yang harus dibuat oleh organisasi dalam proses manajemen organisasi.

Untuk mencapai kinerja organisasi yang unggul, organisasi harus mampu bersaing untuk mendapatkan sumber daya, baik itu sumberdaya manusia maupun sumberdaya finansial. Kedua hal ini merupakan faktor kunci bagi organisasi. Peran kekepmimpinan merupakan faktor kunci pencapainnya. Sebagai contoh: Perusahaan akan bersaing untuk keuntungan, badan amal bersaing untuk sumbangan, lembaga pendidikan bersaing untuk siswa/ mahasiswa dan guru/ profesor terbaik dan tim olahraga bersaing untuk sebuah kejuaraan.

Selanjutnya defenisi lebih singkat di paparkan oleh Dess, Lumpkin, Eisner dan McNamara strategy is the ideas, decisions, and actions that enable a firm to succeed (Dess et al., 2014). Strategi adalah ide-ide, keputusan dan tindakan yang menjadikan organisasi sukses dalm pencapain tujuan. Pengembagan ideide kreatif dan inovatif memberikan kemudahan bagi organisasi dalam pembuatan keputusan bermanfaat. Keputusan tidak banyak bermanfaat jika tidak ditindaklanjuti. Organisasi harus mengambil kebijakan yang diperlukan untuk menerapkan strategi.

Thompson \& Martin (2005) memberikan visualisasi lima cara memandang strategi dalam Gambar 1. Terdapat lima komponen dalam memandang strategi yaitu: visi, perencanaan, taktik, posisi, dan pola. Untuk lebih jelaskan dapat di lihat pada Gambar 1 Berikut:

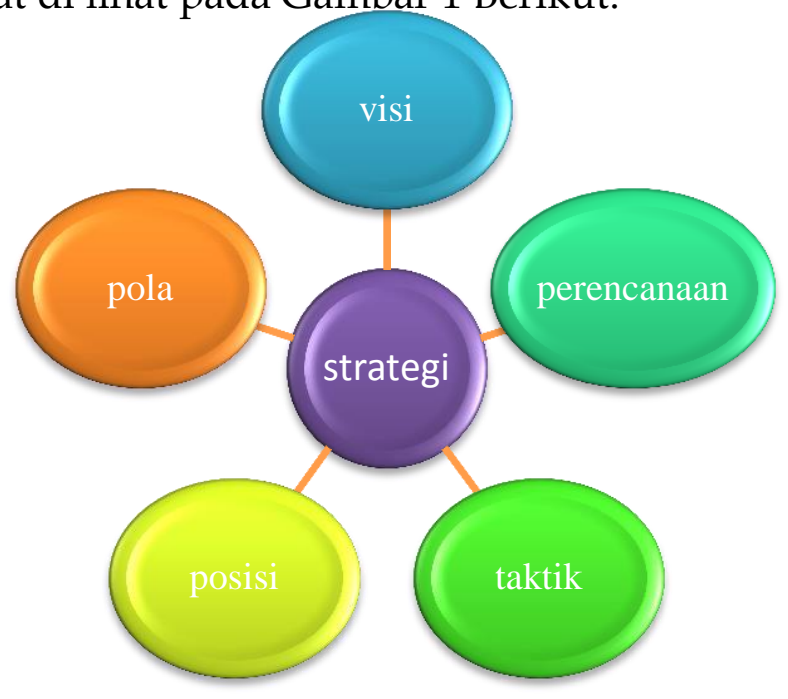

Gambar 1. Lima Komponen Strategi

Gambar 1 menunjukkan bahwa strategi dapat dilihat dalam konteks visioner. Di sini tersirat bahwa strategi dapat dianggap sebagai tujuan strategik 
yang jelas, maksud dan arah sebuah organisasi, akan tetapi tanpa perincian yang jelas. Dalam lingkungan organisasi yang selalu dinamis, para manajer kemudian akan menentukan strategi yang lebih rinci dan spesifik dalam jangka waktu tertentu dan ini merupkan visi organisasi.

Sebagian orang memilki pemikiran bahwaa strategi dan perencanaan adalah dua hal yang sama. Perencanaan strategik memiliki peran penting dalam penciptaan strategi, tetapi perencanaan tidak sepenuhnya menjelaskan bagaimana strategi tersebut.

Taktik juga merupakan pandangan tentang menatap masa depan yang harus segara dilaksanakan. Persaingan organiasi dan perkembangan zaman akan berlangsung sangat dinamis. Semua organisasi akan terus melakukan inovasi-inovasi dan menggunakan cara-cara terbaru dalam upaya pengembangan organisasi. Untuk itu taktik merupakaan cara cepat dalam mengadopsi dan mengatasi persaingan serta kompetisi agar organisasi dapat lebih unggul.

Visi, perencanaan dan taktik semuanya menyangkut masa depan dan menyiratkan perubahan. Posisi berterkaitan dengan kecocokan situasi kompetitif organisasi saat ini. Pada dasarnya, posisi adalah berhenti sementara untuk melihat posisi organisasi saat ini untuk menyadari kondisi organisasi dan kemudian melakukan klarifikasi sehingga perubahan organisasi berdasarkan data dan pengetahuan bukan asumsi masa lalu. Dan tentu saja posisi organisasi saat ini merupakan hasil dari keputusan yang diambil sebelumnya, perencanaan yang telah diimplementasikan dan taktik sebelumnya.

Kemudian hal penting yang dilakukan untuk menganalisis dan memahami pola yang berkembang, melihat apa yang telah terjadi, mengapa dan bagaimana bisa terjadi. Memahami pola bisa menjadi fondasi yang berharga untuk keputusan, rencana dan tindakan di masa depanbagi organisasi, namun walaupun sejarah dapat menjadi panduan untuk masa depan, jarang terjadi peristiwa yang diulang sama persis atau tanpa tanpa beberapa perbedaan. Pentingnya mengklarifikasi pola dari berbagai keputusan dan perubahan juga menjelaskan keberhasilan sebuah strategi.

Pemahaman tentang perspektif ini akan kita dapatkan dan diperkuat ketika kita melihat dan mempraktikkan langsung bagaimana sebuah strategi dibuat oleh organisasi dan diubah sesuai dengan kondisi organisasi, persaingan, perkembangan zaman yang sangat dinamis.

Setelah di paparkan beberapa konsep dari strategi dapat ditarik sebuah kesimpulam bahwa strategi merupakan serangkaian tindakan yang dilakukan oleh organisasi secara terintegrasi untuk membuat keputusan terbaik bagi pencapain tujuan organisasi. Intinya organisasi harus mampu menciptakan strategi-strategi dalam upaya pengembagan organisasinya. Pencipataan dan implementasi strategi memelukan manajemen. Oleh karena itu, pengelola organisasi perlu memahami konsep manajemen strategik.

Manajemen strategik menurut Rothaemel (2017) "strategic management is the integrative management field that combines analysis, formulation, and 
implementation in the quest for competitive advantage". Manajemen strategik adalah bidang manajemen integratif yang menggabungkan analisis, formulasi, dan implementasi dalam upaya mencari keunggulan yang kompetitif bagi organisasi. Kemmapuan menguasai dan memahami manajemen strategik memungkinkan pemimpin mampu melihat organisasi secara keseluruhan. Manajemen strategik juga memungkinkan pemimpin membuat organisasi memilki kinerja yang unggul.

David \& David (2015) menjelaskan "strategic management can be defined as the art and science of formulating, implementing, and evaluating cross-functional decisions that enable an organization to achieve its objectives". Defenisi ini menggambarkan manajemen strategik sebagai seni dan ilmu dalam memformulasi/ merumuskan, menerapkan, dan mengevaluasi keputusan lintas fungsional yang memungkinkan organisasi untuk mencapai tujuannya. Manajemen strategik memiliki fokus pada pengintegrasian beberapa aspek penting yaitu: manajemen, pemasaran, keuangan, produksi dan operasi, penelitian dan pengembangan, serta tak kalah penting yaitu sistem informasi dalam menghasilkan data dan fakta untuk mendukung proses pembuatan keputusan untuk mencapai tujuan organisasi.

Memeperkuat pendapat diatas Dess, Lumpkin, Eisner dan McNamara menegaskan "strategic management consists of the analyses, decisions, and actions an organization undertakes in order to create and sustain competitive advantages" (Dess et al., 2014). Manajemen strategik terdiri dari tiga bagian penting yaitu analisis, keputusan, dan tindakan yang dilakukan oleh suatu organisasi untuk menciptakan dan mempertahankan keunggulan organisasi dan memperbaiki kelemahan organisasi. Ada dua elemen utama dalam manajemen strategik yaitu: Pertama, manajemen strategik dalam organisasi harus memilki tiga proses: analisis, keputusan, dan tindakan. Manajemen strategik juga berkaitan dengan analisis tujuan strategik (visi, misi, dan tujuan strategik) bersama dengan analisis lingkungan internal dan eksternal organisasi. Selanjutnya, para pemimpin harus membuat keputusan strategik. Kedua, esensi manajemen strategik adalah mempelajari tentang mengapa beberapa organisasi lebih unggul dibanding yang lain. Dengan demikian, manajer perlu menentukan bagaimana organisasinya mampu bersaing sehingga dapat unggul dalam pencapain efektivitas organisasi.

Manajemen strategik dapat difahami sebagai proses pengintegrasian antara perumusan/ perencanaan, implementasi/ menerapkan, dan mengevaluasi yang bermuara pada pembuatan keputusan organisasi yang memberikan dampak pada keunggulan organisasi. Pemimpin organisasi menetapkan dan mengawasi keputusan yang dimabil untuk dapat mencapai tujuan. 
Journal Continuous Education

Volume 1, Issue 1, November 2020

Page 11-23

\section{Proses Manajemen Strategik}

Manajemen strategik adalah proses atau proses yang perlu dipahami lebih dari sekedar disiplin imu yang dapat diajarkan. Manajemen strategik adalah proses di mana organisasi menentukan tujuan, sasaran, dan tingkat pencapaian yang diinginkan, keputusan dan tindakan untuk mencapai tujuan dalam skala waktu yang tepat, dalam kondisi lingkungan yang berubah-ubah; implementasi perencanaan; dan menilai kemajuan dan efektivitas organisasi (Thompson \& Martin, 2005). Artinya manajemen strategik merupakan proses komprehensip yang harus dilakukan organisasi dalam menjalan organisasi. Organisasi yang yang mempraktikkan manajemen strategik akan terus mengalami perubahan ke arah yang lebih baik. Hal ini dikarenakan semua tindakan yang dilakukan terukur dan dievaluasi.

Implementasi manajemen strategik dalam organisasi bukan merupakan suatu hal yang mudah. Dibutuhkan pemhaman dan keseriusan semua anggota organisasi. Untuk itu dalam memahami dan imlementasinya manajemen strategik memilki tahapan/ proses.

Sebagaimana diungkapkan oleh Rothaemel (2017) sebelumnya bahwa manajemen strategik proses mengintegrasikan/ menggabungkan analisis, formulasi, dan implementasi (AFI) dalam upaya mencari keunggulan yang kompetitif organisasi. AFI merupakan sebuah kerangka kerja strategi guna mewujudkan pandangan manajemen strategik. Untuk lebih jelanya dapat dilihat pada Gambar berikut ini:

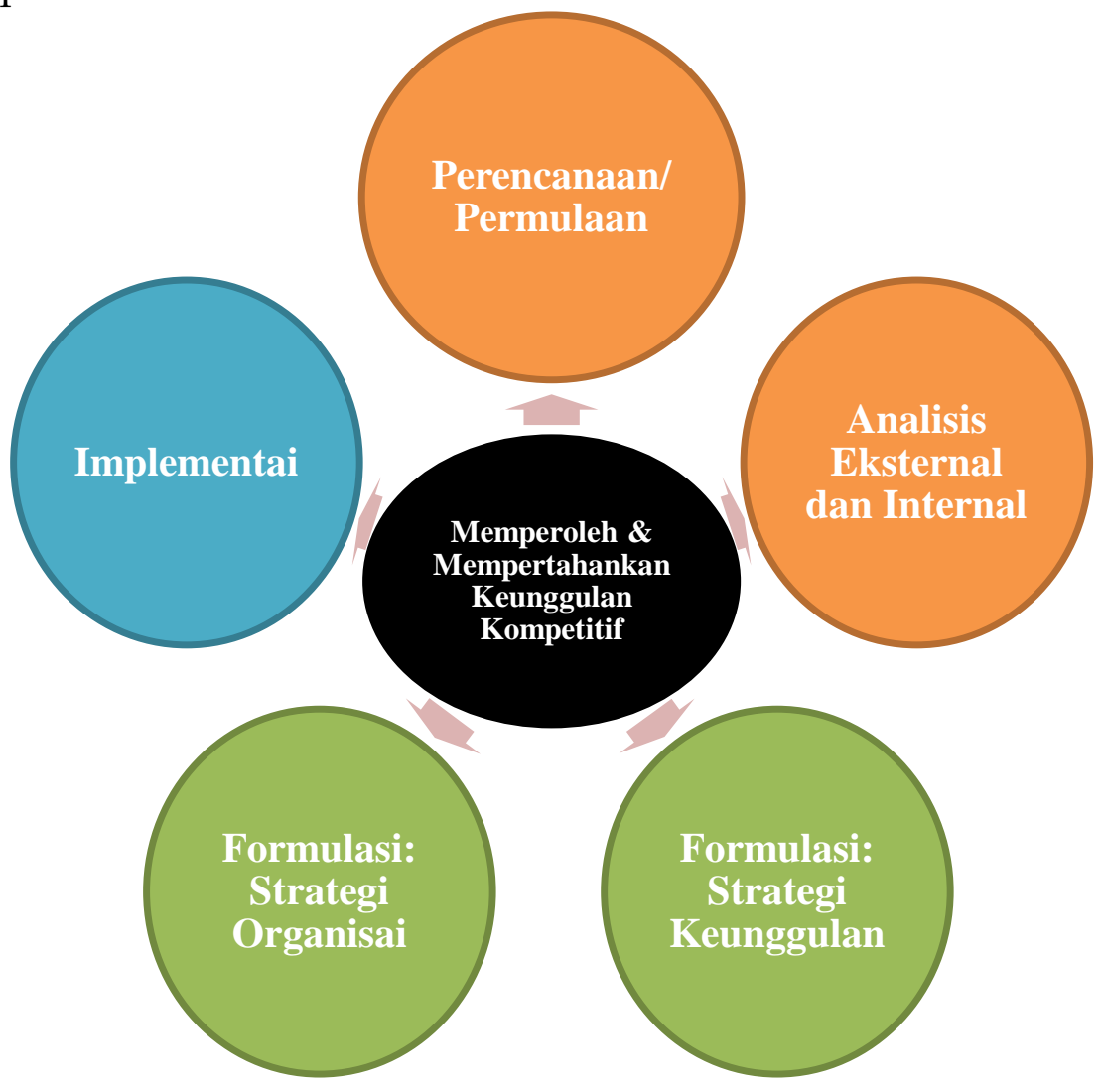

Gambar 2. Kerangka Strategi AFI 
Kerangka strategi AFI yang ditunjukkan pada Gambar 2 diatas, dapat menjelaskan dan memprediksi perbedaan dalam kinerja organisasi, dan membantu manajer dalam merumuskan dan mengimplementasikan strategi yang dapat menghasilkan efektivitas organisasi. Kerangka kerja strategi model AFI menghubungkan tiga tugas manajemen strategik yang saling bergantung (menganalisis, merumuskan, dan mengimplementasikan) dan membantu para manajer untuk dalam menghasilkan keunggulan kompetitif.

Proses manajemen strategik dalam menyusun dan melaksanakan strategi organisasi merupakan proses yang berkelanjutan yang terdiri dari lima tahapan yang terintegrasi:

1. Developing a strategic vision (Mengembangkan visi strategik yang menggambarkan arah jangka panjang organisasi, pernyataan misi yang sesuai dengan organisasi, dan serangkaian nilai inti untuk memandu anggota organisasi dalam mewujudkan visi dan misi strategik)

2. Setting objectives (Menetapkan tujuan untuk mengukur kinerja organisasi dan memantau kemajuannya dalam bergerak ke arah jangka panjang sesuai dengan tujuan organisasi)

3. Crafting a strategy (Membuat strategi untuk kemajuan organisasi menuju masa depan yang diharapkan oleh manajemen dan mencapai tujuan kinerja yang unggul).

4. Implementing and executing the chosen strategy (Menerapkan dan melaksanakan strategi yang telah di tetapkan secara efektif dan efisien).

5. Evaluating and analyzing the external environment and the company's internal situation and performance (Mengevaluasi dan menganalisis lingkungan eksternal dan situasi internal organisasi serta kinerja untuk mengidentifikasi kesesuaian antara perencanaan dan strategi yang ditetapkan. Kemudian apabila kurang sesuai perlu dikoreksi untuk kemajuan jangka panjang organisasi) (Gamble et al., 2015).

Kelima tahapan ini merupakan satu kesatuan yang harus di praktikkan oelh organisasi melalui kepemimpinan yang baik. Setiap tahapan harus mendapatkan perhatian organisasi guna mencapai tujuan yang di inginkan dan telah di rumuskan kedalam sesbuah strategi.

Proses manajemen strategik menurut David \& David (2015) terdiri dari tiga tahap yaitu: 1) perumusan strategi, 2) implementasi strategi, dan 3) evaluasi strategi.

Perumusan strategi memiliki banyak aspek atau tugas didalamnya. Mulai dari mengembangkan visi dan misi, mengidentifikasi peluang dan ancaman dari eksternal organisasi, menentukan kekuatan dan kelemahan diinternal organisasi, menetapkan tujuan jangka panjang, mengembangkan strategi alternatif, dan memilih strategi tertentu untuk diimplementaikan. Tidak ada organisasi yang memiliki sumber daya tak terbatas, untuk mengatasssi keterbatasan itu, organisasi penting membuat dan memutuskan strategi alternatif mana yang paling menguntungkan organisasi. Pemimpin memiliki harus memilki perspektif terbaik untuk memahami sepenuhnya konsekuensi 
dari keputusan dalam perumusan strategi; dan pemimpin memiliki wewenang untuk memilih sumber daya yang diperlukan untuk implementasi strategi.

Implementasi strategi merupakan tahapan kedua dalam proses manajemen trategik. Menerapkan strategi berarti menggerakkan seluruh anggota organissasi dan manajer untuk menerapkan strategi yang telah dirumuskan sebelumnya dalam sebuah tindakan. Implementasi strategi sering dianggap sebagai tahap yang paling sulit dalam manajemen strategik, oleh karena itu implementasi strategi memerlukan kedisiplinan, komitmen, dan pengorbanan dari seluruh anggota organisasi. Keberhasilan dalam implementasi strategi sangat bergantung pada kemampuan pemimpin untuk mempengaruhi, menggerakkan dan memotivasi karyawan. Implementasi strategi termasuk mengembangkan budaya organisasi, menciptakan struktur organisasi yang efektif, menyiapkan anggaran, mengembangkan dan menggunakan sistem informasi, dan menghubungkan kompensasi karyawan dengan kinerja organisasi.

Tahap akhir dari proses manajemen strategik adalah evaluasi strategi. Pemimpin harus mengawasi dan mengevaluasi untuk mengetahui bahwa strategi yang telah di rumuskan dan diimplementasikan berjalan dengan baik atau tidak berjalan dengan baik. Evaluasi strategi adalah sarana utama untuk memperoleh informasi ini. Evaluasi perlu dilakukan dengan baik walaupun pada saat perumusan dan awal implementasi sudah dilakuakn dengan matang. Hal ini disebabkan karena dinamisnya faktor eksternal dan internal. Dalam evaluasi strategi ada tiga hal mendasar yang harus dilakukan yaitu: (1) memantau faktor eksternal dan internal yang merupakan dasar penyusunan strategi, (2) mengukur kinerja, dan (3) mengambil tindakan korektif.

Perumusan, implementasi, dan evaluasi kegiatan strategi terjadi pada setiap jenjang dalam organisasi. Dengan mengembangkan komunikasi dan interaksi di antara para manajer dan karyawan di seluruh elemen organisasi dapat meningkatkan keberhasilan strategi. Melibatkan seluruh anggota organisasi bukan hal yang mudah dalam proses manajemen strategik. Namun, para manajer harus mampu meilibatkan secara aktif anggota organisasi untuk dapat menciptakan efektivitas organisasi dan keunggulan organisasi.

\section{Manajemen Strategik di Lembaga Pendidikan}

Layaknya pada organisasi-organisasi profit, organisasi/ lembaga pendidikan perlu memliki strategi dalam upaya pengembangannya. Terlebih lembaga pendidikan di Indonesia yang belum dapat dikatakan berkualitas secara umum. Imlementasi manajemen strategik dirasa sangat diperlukan.

Di banyak negara upaya peningkatan mutu pendidikan merupakan isu yang sangat strategik dan merupakan prioritas bagi pemerintah disamping ekonomi dan kesehatan. Oleh karena itu ada tekanan besar bagi pengelola sekolah untuk meningkatkan mutu yang lebih baik. Beberapa aspek yang menjadi perhatian publik adalah: student results (prestasi siswa), participation rates (tingkat partisipasi/ APK), inclusion and results for previously disadvantaged groups (pendidikan inklusi bagi anak yang berkebutuhan khusus), parental 
satisfaction with schooling (kepuasan orangtua), employer satisfaction with the products of schooling (kepuasan pengguna lulusan), cost-effectiveness of schooling (efektivitas biaya sekolah) (Fidler, 2002).

Kelima aspek di atas hendaknya menjadi perhatian pengelola sekolah mulai dari Pemerintah Pusat, Pemerintah Daerah dan Kepala Sekolah. Kelima aspek ini akan terus menjadi isu strategik dan berkembang apabila belum ditemukan solusinya. Sementara itu Fidler (2002) mengembangkan model perencanaan strategik untuk sekolah melalui tiga tahap konseptual yaitu: 1) analisis strategi, 2) pemilihan strategi dan 3) implementasi strategik. Model yang ditwarkan Fidler ini tidak memilki evaluasi dalam implementasi perencanaan strategik ini.

Sagala (2010) merumuskan lima hal yang harus dilakukan pihak sekolah dalam implementasi manajemen strategik yaitu: 1) formulasi visi dan misi sekolah, 2) tujuan dan target sekolah, 3) penentuan strategi organisasi sekolah, 4) implementasi strategi organisasi sekolah, dan 5) analisis SWOT secara cermat dan akurat. Sekolah akan memiliki arah dan tujuan yang jelas jika memilki kelima hal implementasi manajemen strategik. Namun kenyataannya banyak sekolah-sekolah yang justru tidak memilki perencanaan dalam upaya menciptakan sekolah unggul.

Selanjutnya pendapat yang hampir sama diungkapkan oleh Courtney (2002) dengan model klasik perencanaan strategik. Model ini merincikan tujuh tahapan dalam perencanaan strategik yaitu: 1) visi, misi dan nilai-nilai, 2) tujuan jangka panjang, 3) strategi priorotas, 4) indikator kinerja, 5) tujuan operasional tahunan, 6) kebutuhan sumber daya (fisik, manusia, keuangan), 7) memantau dan melaksanakan perencanaan operasional sesuai jadwal. Untuk lebih jelasnya dapat dilihat pada gambar 3 berikut ini:



Gambar 3. Piramida Perencanaan Strategik 
Formulasi manajemen strategik di lembaga pendidikan harus dimulai dengan melakukan analisis lingkungan internal dan eksternal sekolah dan kemudian mengumpulkan data, melakukan perumusan visi, misi, tujuan dan sasaran sekolah, yang berorientasi pada masa depan dan keunggulan sekolah. Visi, misi sekolah harus disusun bersama dengan seluruh stakeholder sekolah mulai dari internal maupun eksternal. Pihak eksternal perlu dihadirkan karena mereka yang akan menggunakan jasa para alumni. Untuk itu perlu didengar kebutuhan pasar/ masyarakat.

Implementasi strategi berarti berupaya memanfaatkan seluruh sumberdaya sekolah baik sumberdaya manusia (Kepala Sekolah, Guru dan staff) maupun sumberdaya keuangan dan fasilitas. Di Indonesia ada Standar Nasional Pendidikan (SNP) harus di wujudkan yang terdiri dari delapan standar yaitu: Standar Kompetensi Lulusan, Standar Isi, Standar Proses, Standar Pendidikan dan Tenaga Kependidikan, Standar Sarana dan Prasarana, Standar Pengelolaan, Standar Pembiayaan Pendidikan dan Standar Penilaian Pendidikan. Keberhasilan implementasi strategi ini sangat bergantung kepada Kepala sekolah untuk mempengaruhi, menggerakkan dan memotivasi guru staf dan siswa. Implementasi strategi memerlukan kedisiplinan, komitmen, dan pengorbanan dari seluruh anggota organisasi.

Kepala sekolah dan guru harus secara rutin dan terjadwal melakukan evaluasi terhadap strategi yang telah di implementasikan. Perubahan yang sangat cepat dan dinamis di lembaga pendidikan sangat berpengaruh dalam keberhasilan pencapaian strategi. Perubahan kurikulum sebgai contoh yang sering terjadi memerlukan sikap cepat dan tanggap personel sekolah untuk mengatasinya. Untuk evaluasi pada siswa bisa diadakan tes atau ujian secara berkala dan bagi tenaga pendidik dan kependidikan bisa dilakukan dengan supervisi dan uji kompetensi.

Pemimpin perlu memiliki kompetensi yang komprehensif untuk mencapai keberhasilan implementasi manajemen strategi. Implementasi manajemen strategi sangat bergantung pada kepemimpinan yang kuat sangat terutama dalam memotivasi untuk mengatasi perbedaan (Zellweger Moser, 2007; Barbón Pérez \& Fernández Pino, 2018). Pemimpin pendidikan merupakan variabel kunci dalam melaksanakan manajemen strategik di lembaga pendidikan.

\section{KESIMPULAN}

Implementasi manajemen strategik dalam pendidikan merupakan sebuah kebutuhan bahkan keharusan. Rendahnya mutu pendidikan kita secara umum, disebabkan lembaga pendidikan belum mampu menetapkan tujuan secara efektif dan efisien menuju keunggulan yang kompettitif. Lembaga pendidikan di Indonesia sebahagian besar belum mampu menyusun strategi untuk mengatasi permsalahan pendidikan yang semakin kompleks. Perkembagan zaman yang begitu dinamis, perekonomian yang tidak stabil, dan pembiayaan yang belum mencukupi mengharuskan lembaga pendidikan meyusun (formulasi) strategi, kemudian mengimplementasikannya, dan terus 
Journal Continuous Education

Volume 1, Issue 1, November 2020

Page 11-23

menilai dan mengevaluasinya. Jika lembaga pendidikan mampu melakukan manajemen strategik dengan baik maka upaya peningkatan dan relevansi pendidikan akan terwujud.

\section{DAFTAR PUSTAKA}

Baltabayeva, Z. B., Sautieva, F. B., Skorobogatova, A. G., \& Mamatelashvili, O. V. (2020). The impact of success factors on the strategic management in an educational complex. Revista Amazonia Investiga, 9(29), 336-346. https:// doi.org/10.34069/AI/2020.29.05.38

Barbón Pérez, O. G., \& Fernández Pino, J. W. (2018). Rol de la gestión educativa estratégica en la gestión del conocimiento, la ciencia, la tecnología y la innovación en la educación superior. Educación Médica, 19(1), 51-55. https:// doi.org/10.1016/j.edumed.2016.12.001

Courtney, R. (2002). Strategic Management for Voluntary Nonprofit Organizations. Routledge.

Danandjaja, J. (2014). Metode Penelitian Kepustakaan. Antropologi Indonesia, 52, 82-92. https://doi.org/10.7454/ai.v0i52.3318

David, F. R., \& David, F. R. (2015). Strategic Management Concepts and Cases. Pearson.

Dess, G. G., Lumpkin, G. T., Eisner, A. B., \& McNamara, G. (2014). Strategic Management: Text and Cases. McGraw-Hill Education.

Fidler, B. (2002). Strategic Management for School Development. Paul Chapman Publishing.

Gamble, J. E., Peteraf, M. A., \& Arthur A. Thompson, J. (2015). Essentials of Strategic Management: The Quest for Competitive Advantage. McGraw-Hill Education.

Hitt, M. A., Ireland, R. D., \& Hoskisson, R. E. (2011). Concepts Strategic Management Competitiveness \& Globalization. Cengage Learning.

Kesner, I. F. (2017). The Strategic Management Course: Tools and Techniques for Successful Teaching. In The Blackwell Handbook of Strategic Management (pp. 675-701). Blackwell Publishing Ltd. https:// doi.org/10.1111/b.9780631218616.2006.00026.x

Latorre-Medina, M. J., \& Blanco-Encomienda, F. J. (2013). Strategic Management as Key to Improve the Quality of Education. Procedia - Social and Behavioral Sciences, 81, 270-274. https://doi.org/10.1016/j.sbspro.2013.06.426

Lestarini, A. H. (2014). Rangking Mutu Pendidikan RI di Dunia Paling Jeblok. News Okezone Com. https://news.okezone.com/read/2014/05/13/373/984246/rangkingmutu-pendidikan-ri-di-dunia-paling-jeblok

Mappasiara. (2018). Manajemen Strategik dan Manajemen Operasional Serta Implementasinya pada Lembaga Pendidikan. Idaarah: Jurnal Manajemen Pendidikan, 2(1), 74-85. https:// doi.org/10.24252/idaarah.v2i1.5116

Rothaemel, F. T. (2017). Strategik Management Concept. McGraw-Hill Education. Sagala, S. (2010). Manajemen Strategik dalam Peningkatan Mutu Pendidikan. Alfabeta. 
Journal Continuous Education

Volume 1, Issue 1, November 2020

Page 11-23

Sampurno. (2013). Manajemen Strategik: Menciptakan Keunggulan Bersaing yang Berkelanjutan. UGM Press.

Sari, M., \& Asmendri. (2020). Penelitian Kepustakaan (Library Research) dalam Penelitian Pendidikan IPA. Natural Science: Jurnal Penelitian Bidang IPA Dan Pendidikan IPA, 6(1), 41-53.

Stukalina, Y. (2010). The Management of Integrated Educational Environment Resources: the factors to be considered. European Journal of Education, 45(2), 345-361. https:// doi.org/10.1111/j.1465-3435.2010.01433.x

Thompson, J., \& Martin, F. (2005). Strategic Management Awareness and Change. Cengage Learning Business Press.

Zed, M. (2014). Metode Penelitian Kepustakaan. Pustaka Obor.

Zellweger Moser, F. (2007). Strategic Management of Educational Technology The Importance of Leadership and Management. Tertiary Education and Management, 13(2), 141-152. https:/ / doi.org/10.1080/13583880701238407 